\title{
Diesel engine performance evaluation on transesterified gmelina seed oil catalysed by thermally modified Iyi-Nsukka kaolin clay catalyst compared to fossil diesel and blends

\author{
${ }^{1}$ Odenigbo J.O., ${ }^{2}$ Chime T.O., ${ }^{2}$ Egbuna S.O.
}

\author{
${ }^{1}$ Engineering Research Development Production Department, Projects Development Institute (PDODA) Enugu, P.M.B.1609
} Enugu, Nigeria.

${ }^{2}$ Department of Chemical Engineering, Enugu State University of Science and Technology, P.M.B.1660,

Enugu State, Nigeria.

Correspondence: +2348038993501; Email: judeodenigbo2@gmail.com.

\begin{abstract}
The thermally modified Iyi-Nsukka kaolinite clay catalyst (TMIKCCat800) was prepared and characterised by X-ray Diffraction (XRD), Fourier transform infrared spectroscopy (FTIR), Scanning electron microscopy (SEM) and Atomic abrasion spectrophotometry (AAS) to verify catalyst properties. Gmelina seed oil was extracted using Soxhlet extraction method using hexane as solvent. The percentage oil extracted from Gmelina seed oil was 50\%, proven its viability as feedstock for biodiesel production. The extracted lipid was characterised to determine the fatty acid profile using Gas chromatography/ Mass Spectroscopy (GC/MS) Shimadzu, Japan. The methyl ester produced by transesterification of gmelina seed oil was within acceptable limits of ASTM Standard. Central composite design (CCD) of Response Surface Methodology (RSM) was used and was adequate in predicting and optimizing the biodiesel production, the optimal process parameters include: reaction time 3 hours, catalyst concentration 3 wt. percent, methanol/oil ratio $12: 1$, reaction temperature $60^{\circ} \mathrm{C}$ and agitation speed 300rpm with $95 \%$ yield of biodiesel. The performance of biodiesel produced from gmelina seed oil (B100), fossil diesel (B0) samples and their blends namely: B20, B40, B60, B80 respectively were carried out using Diesel engine test bed power rating: 112kw / 150hp; engine model: Perkins 4:108, engine number: 108U7258, 4-strokes, 4-cylinders maximum speed: 3000rpm, water cooled. The exhaust gas was analysed using gas analyser. It was observed that the performance of B20 and B0 (petro-diesel) was very similar but B20 was environmentally friendly.
\end{abstract}

Index term-Diesel engine performance, exhaust emission, gmelina biodiesel, thermally modified Iyi-Nsukka kaolin clay catalyst, fossil diesel, blends

\section{Introduction}

Biodiesel as an alternative fuel to petro diesel has received enormous research attention in recent years due to fast depletion of petro diesel resources and its environmental pollution effects (Yusoff et al., 2020; Ghaly et al., 2010). Biodiesel show similar properties to standard petro diesel. The high viscosity of vegetable oil makes it inefficient fuel for direct use in existing diesel engines, the engine got choked after few hours when they are directly run on vegetable oil (Vashist, 2014). Transesterification has been accepted world-wide as an effective route for biodiesel production and viscosity reduction on vegetables oil, by the chemical approach it is a well-developed technology that has been commercialized world wide (Faruque et al.,2020; Srivastava and Prasad, 2000; Mittelbach and Remschmidt, 2006; Meher et al., 2006;
Demirbas, 2009; Knothe, 2009; Sharma et al 2011a; Talebian-kiakalieh et al., 2013; Hama and kondo, 2013; Atadashi et al., 2013; Sani et al., 2014). In trans-esterification reaction, catalysts are used to improve the yield of biodiesel production. These catalysts can be classified, according to their chemical presence in the reaction, as homogeneous or heterogeneous catalysts. Homogeneous catalysts act in the same liquid phase as the reaction mixture, whereas heterogeneous catalysts act in a different phase from the reaction mixture, usually as a solid (Singh, 2010). Heterogeneous catalysts are noncorrosive, a green process and environmentally friendly. They can be recycled and used several times, thus offering a more economic pathway for biodiesel production. From the process point of view, to recover the catalyst do not require aqueous treatment and purification steps so giving more 
simplified and very high yields of methyl ester (Talebian-Kiakalaieh, 2013).

The most notable catalyst used in producing biodiesel is the homogeneous alkaline catalyst such as $\mathrm{NaOH}, \mathrm{KOH}, \mathrm{CH}_{3} \mathrm{ONa}$ and $\mathrm{CH}_{3} \mathrm{OK}$. The choice of these catalysts is due to their higher kinetic reaction rates. However, because of high cost of refined feedstocks and difficulties associated with use of homogeneous alkaline catalysts to transesterify low quality feedstocks for biodiesel production. Development of various heterogeneous catalysts are now on the increase majorly on assessing the accessibility of the catalysts, cost effectiveness, recovery and reusability of the catalyst. This investigation studied thermally modified kaolin clay catalyst as stable, cost effective, accessible, and recovery of catalyst.

\section{Experimental}

Thermally modified Iyi-Nsukka kaolin clay catalyst (TMIKCCat800) was prepared according to the method of (Xu et al., 2010). The sample was pulverized, sieved with sieve size of $250 \mu \mathrm{m}$ and placed in a laboratory muffle furnace for activation at $800^{\circ} \mathrm{C}$ for 4 hours. The unmodified Iyi-Nsukka kaolin clay catalyst (UMIKCCat) sample was pulverized, sieved with sieve size of $250 \mu \mathrm{m}$ and oven dried at $150^{\circ} \mathrm{C}$ for 4 hours as control.

$$
\text { Catalysts Characterisation- X-ray }
$$

Diffraction (XRD) of unmodified and thermally modified Iyi-Nsukka kaolinite clay catalyst were determined using an EMPYREAN Diffractometer manufactured by PA analytical, operating at generator voltage: $45 \mathrm{kv}$, tube current: $40 \mathrm{~mA}$ and measurement temperature: $25^{\circ} \mathrm{C}$. The Fourier transform infrared spectra (FTIR) of the kaolin clay catalysts samples were done by the use of the FTIR spectrophotometer using transmittance method with range 4000 - 650 wavenumber $\left(\mathrm{cm}^{-1}\right)$. To show the functional group present in these catalysts samples. Scanning electron microscope (SEM) of the kaolin clay catalysts samples were done using Scanning electron microscope (SEM) model: Phenom ProX, manufactured by Eindhoven, Netherland to show the morphology of the catalysts. Atomic Absorption Spectrophotometry (AAS) of clay catalysts were done using Atomic Absorption Spectrophotometer 210VGP, manufactured by Buck Scientific, England.

The performance of biodiesel produced from Gmelina (B100), fossil diesel (B0) samples and their blends namely: B20, B40, B60, B80 respectively were carried out using Diesel engine test bed power rating : $112 \mathrm{Kw} / 150 \mathrm{hp}$; engine model: Perkins 4:108, engine number: 108U7258, 4strokes, 4-cylinders maximum speed :3000rpm, water cooled. Hydraulic dynamometer model number: DPX2, make: Heenan \& Froude; maximum speed 7500rpm.

Prior to the tests, all round examination test were made, the position of all controls were noted and features such as the engine throttle and stop control were checked for proper functioning, fuel supply, lubricant and cooling water operation and circulation system test by starting the pumps without engine running. After checking the general testing procedure and ambient conditions noted, the engine was started and kept at speed of $1500 \mathrm{rpm}$, the value of the torque was recorded. The time for a given volume of $100 \mathrm{~cm}^{3}$ of fuel to be consumed at this speed is noted using the fuel gauge. The manometer reading was noted as well as the exhaust temperature, oil temperature and pressure. Readings in the two water cooling systems of both the engine and the dynamometer load, water in lets and out lets temperatures were noted. The above procedure were repeated for higher speeds values $1750 \mathrm{rpm}, 2000$ rpm, 2250rpm and 2500rpm, respectively. The exhaust gas was noted with gas analyser

\section{Results and Discussion}

Figure 1 and Figure 2 show the XRD of UMIKCCat and TMIKCCat800 respectively. The visible compounds include: Quartz, kaolinite and hematite, with displacements: $0.000 ; 0.000$ and $0.000[\AA]$ at $\left[{ }^{\circ} 2 \mathrm{Th}\right]$ and chemical formula: $\mathrm{Si}_{3} \mathrm{O}_{6}$; $\mathrm{Al}_{2} \mathrm{Si}_{2} \mathrm{O}_{9}$ and $\mathrm{Fe}_{12} . \mathrm{O}_{18}$, respectively. As a result of the thermal modification, hematite became present while alumina content and percentage weight decreased. This observation is in line with the findings of Panda et al., (2010) and Maryam et al., (2014).

Figure 3 and Figure 4 show the FTIR of UMIKCCat and TMIKCCat800 respectively. The band at $2199.1 \mathrm{~cm}^{-1}$ was ascribed to C-H stretching, the band at $1058.6 \mathrm{~cm}^{-1}$ represents $\mathrm{Si}-\mathrm{O}$ stretching possibly, the band at $779.0 \mathrm{~cm}^{-1}$ was ascribed to $\mathrm{OH}$ deformation while the band at $693.3 \mathrm{~cm}^{-1}$ was assigned to Si-O quartz. Thermal modification led to disappearance of the band at $3623.0 \mathrm{~cm}^{-1}$ assigned to Al---O-H stretching as seen in the unmodified IyiNsukka kaolin clay catalyst. This observation is in line with the findings of Maryam et al., (2014),

Plate 1 and Plate 2 show the SEM of UMIKCCat and TMIKCCat800 respectively. The SEM micrograph show more disaggregation and disintegrations of structure of the particles of the clay sheet upon thermal modification at $800^{\circ} \mathrm{C}$. The micrograph indicate more porous surfaces and decrease in particle weight when compared to unmodified IyiNsukka kaolin clay catalyst in which the SEM micrograph shows agglomeration of particles and interlocking of kaolinite particles with aggregate arrangement. The result is in line with the findings 
of Panda et al. (2010). Table 1 shows the elemental compositions of catalysts, the result shows that the dominant elements are $\mathrm{Al}_{2} \mathrm{O}_{3}$ and $\mathrm{SiO}_{2}$. The results is similar to the findings of Panda et al. (2010), Oueda et al. (2017) and Park et al. (2008). Table 2 shows the physiochemical properties of catalysts, it can be observed that there is increase in surface area

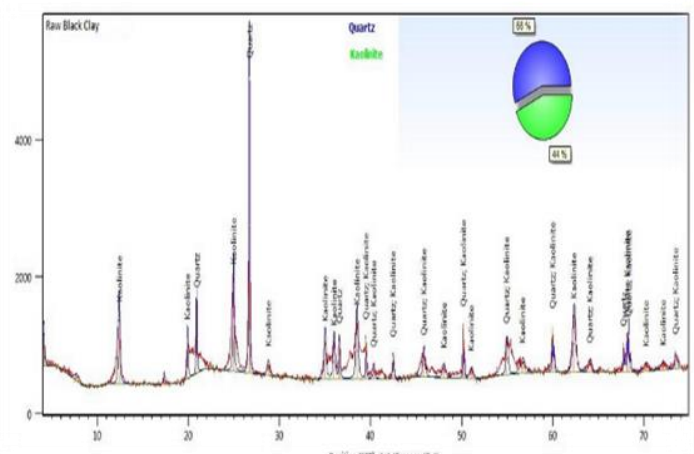

Figure 1: XRD of UMIKCCat

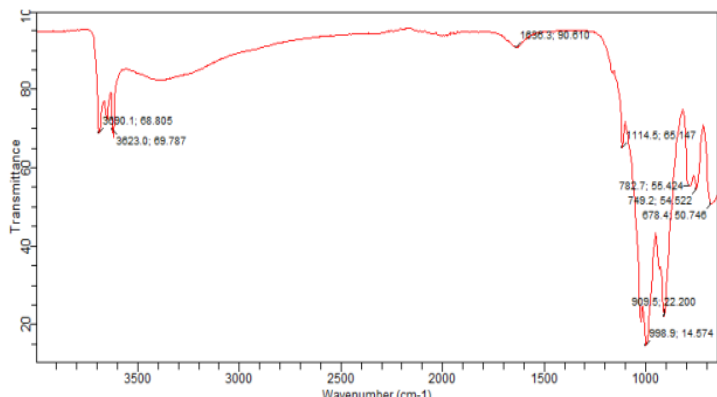

Figure 3: FTIR of UMIKCCat from $\left(721-785 \mathrm{~m}^{2} \mathrm{~g}^{-1}\right)$ and porosity from (51.75$57.37 \%$ ) as a result of thermal modification of the catalyst. Table 3 shows physiochemical properties of gmelina seed oil while Table 4 represent the properties of fossil diesel, gmelina biodiesel and blends compared with ASTM D675

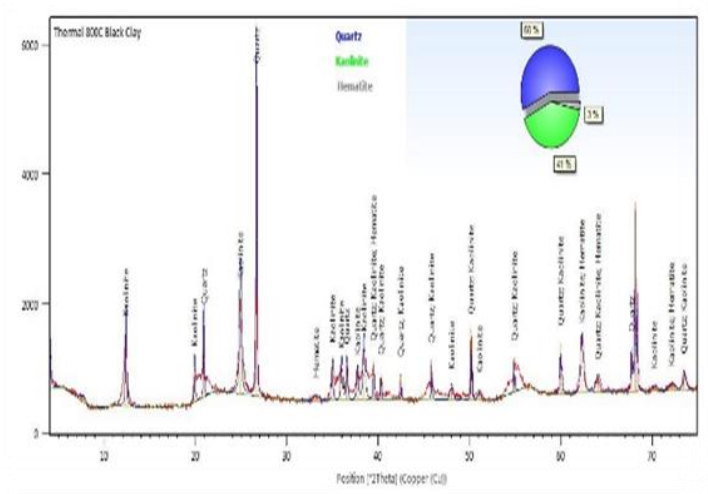

Figure 2: XRD of TMIKCCat800
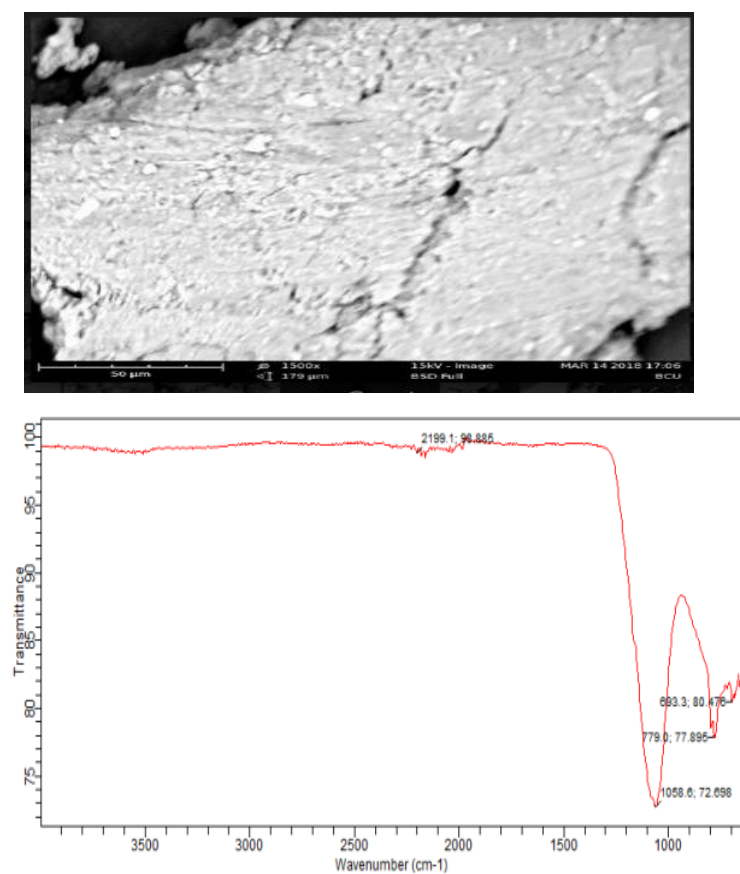

Figure 4: FTIR of TMIKCCat800

Plate 1: SEM of UMIKCCat 


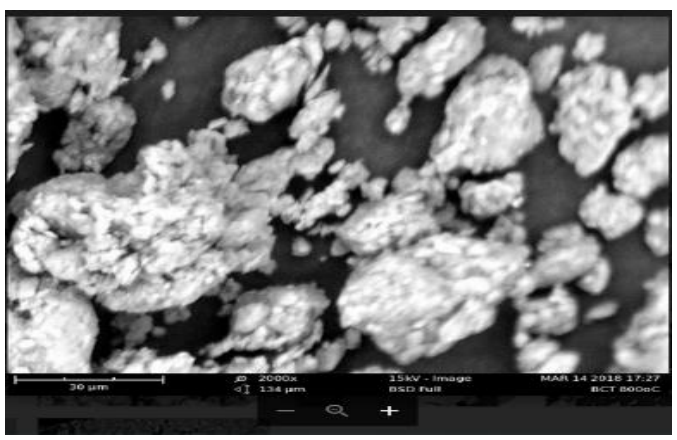

Plate 2: SEM of TMIKCCat800

Table 1: Elemental compositions of catalysts

\begin{tabular}{ccc}
\hline Composition & UMIKCCat & TMIKCCat800 \\
\hline $\mathrm{Al}_{2} \mathrm{O}_{3}$ & 44.00 & 41.00 \\
$\mathrm{SiO}_{2}$ & 56.00 & 56.00 \\
$\mathrm{Fe}_{2} \mathrm{O}_{3}$ & 0.00 & 3.00 \\
$\mathrm{ZnO}$ & 0.00 & 0.00 \\
$\mathrm{TiO}_{2}$ & 0.00 & 0.00 \\
$\mathrm{~K}_{2} \mathrm{O}$ & 0.00 & 0.00 \\
$\mathrm{MgO}$ & 0.00 & 0.00 \\
$\mathrm{MnO}$ & 0.00 & 0.00 \\
$\mathrm{Na}_{2} \mathrm{O}$ & 0.00 & 0.00 \\
\hline
\end{tabular}

Table 2: Physiochemical properties of catalysts

\begin{tabular}{llll}
\hline Parameters & UMIKCCat & TMIKCCat800 & Range \\
\hline Moisture (\%) & 0.13 & 0.09 & $\geq 0.05$ \\
Bulk Density $\left(\mathrm{g} \mathrm{cm}^{-3}\right)$ & 0.81 & 1.33 & $0.8-1.3$ \\
$\mathrm{pH}$ & 2.27 & 8.41 & $2-4.6$ \\
Surface Area $\left(\mathrm{m}^{2} \mathrm{~g}^{-1}\right)$ & 721 & 785 & $670-800$ \\
Carbon $(\%)$ & 4.11 & 1.66 & $1-6$ \\
Organic Matter $(\%)$ & 12.19 & 4.92 & $5-15$ \\
Loss On Ignition $(\%)$ & 29.40 & 13.30 & $13-30$ \\
Particle Density $\left(\mathrm{g} \mathrm{cm}^{-3)}\right.$ & 2.60 & 2.09 & $2.1-2.6$ \\
Total porosity $(\%)$ & 51.75 & 57.37 & $51-58$ \\
\hline
\end{tabular}

Table 3: Physiochemical properties of gmelina seed oil

\begin{tabular}{lll}
\hline Properties & gmelina seed oil & Range \\
\hline Specific gravity & 0.92 & $0.860-0.92$ \\
Kinematics viscosity $\left(\mathrm{mm}^{2} / \mathrm{s}\right)$ at $40^{\circ} \mathrm{C}$ & 5.2 & $1.9-6.0(\mathrm{ASTM} / \mathrm{D} 445)$ \\
Free fatty acid $(\mathrm{mg} \mathrm{K0H} / \mathrm{Kg})$ & 1.53 & $\leq 3(\mathrm{ASTM})$ \\
Iodine value $(\mathrm{g} / 100 \mathrm{~g})$ & 36.50 & $\leq 90(\mathrm{EN} 14111)$ \\
Density $(\mathrm{g} / \mathrm{ml})$ & 1.48 & $196-205$ \\
Saponification value $(\mathrm{mg} \mathrm{KOH} / \mathrm{Kg})$ & 161.49 & \\
& 1.4985 & $1.447-1.490$ \\
Refractive index & 0.91 & $0.1-5(\mathrm{ASTM})$ \\
Peroxide value Meq/Kg & 0.10 & $\leq 0.1(\mathrm{ASTM})$ \\
Moisture content $(\%)$ & &
\end{tabular}


Table 4: Properties of fossil diesel, gmelina biodiesel and blends compared with ASTM D6751

\begin{tabular}{|c|c|c|c|c|c|c|c|c|}
\hline Properties & Units & ASTM Limits & B0 & B20 & B40 & B60 & B80 & B100 \\
\hline Density & $\mathrm{kg} / \mathrm{m}^{3}$ & $830-880$ & 835 & 843 & 854 & 864 & 874 & 862 \\
\hline Kinematics Viscosity & $\mathrm{Mm}^{2} / \mathrm{s}$ & $1.6-6.0$ & 3.2 & 3.5 & 3.9 & 4.3 & 4.61 & 4.96 \\
\hline Flash Point & ${ }^{\circ} \mathrm{C}$ & 130 Min. & 68 & 80 & 99 & 120 & 148 & 154 \\
\hline Fire Point & ${ }^{\circ} \mathrm{C}$ & 150 Min. & 82 & 97 & 112 & 127 & 142 & 160 \\
\hline Pour Point & ${ }^{\circ} \mathrm{C}$ & +15 & 3.5 & 57 & 69 & 82 & 93 & 107 \\
\hline Cloud Point & ${ }^{\circ} \mathrm{C}$ & $-3-12$ & -3 & -2 & -1 & 1 & 4 & 7 \\
\hline Aniline Point & ${ }^{\circ} \mathrm{C}$ & - & - & 80 & 83 & 85 & 87 & 89 \\
\hline Cetane index & ${ }^{\circ} \mathrm{C}$ & 40 Min. & 42 & 46 & 50 & 56 & 60 & 64 \\
\hline Cetane Number & ${ }^{\circ} \mathrm{C}$ & 47Min. & 47 & 49 & 51 & 53 & 54 & 56 \\
\hline Calorific & $\mathrm{KJ} / \mathrm{KG}$ & - & 44,200 & 43,364 & 42,528 & 41,692 & 40,856 & 40,020 \\
\hline Value & & & & & & & & \\
\hline
\end{tabular}

Variation of engine speed with torque.

Figure 5: Shows the plot of engine torque against speed for biodiesel, biodiesel blends and fossil diesel at full load. From the Figure 5, the torque increases as the engine speed increases up to 2000rpm and started decreasing. However, the torque of the engine with fossil diesel was higher than biodiesel and its blends. This may be attributed to low calorific value of biodiesel, the observation in similar to the findings of Dhamaparrabhakaran and karthikeyan, 2020; Panda et al., 2010 and Hussain et al., 2020.

Variation of engine speed with brake specific fuel consumption (BSFC)

Figure 6: BSFC decreases with the increase in engine speed until minimum BSFC were found at about $2000 \mathrm{rpm}$ and then it increased with increase in engine speed until $2500 \mathrm{rpm}$. The similar trend was also reported by Omidvarborna, (2016). Brake specific fuel consumption is the rate of fuel consumption per unit brake power. It is a measure of efficiency of the engine in utilizing fuel supplied to produce work. It is desirable to obtain a lower value of BSFC, the engine used less fuel to produce the same amount of work. Also it was observed that Fuel consumption increased when using biodiesel, but this trend reduced as the proportion of biodiesel reduces in the blends fuel with fossil diesel, the observation is in line with the findings of Mujtaba et al., 2020; Hussain et al., 2020 and Faruque et al., 2020 . B100 has the highest BSFC this may be due to its low heating value. B20 has the lowest and best BSFC.

Variation of engine speed with brake thermal efficiency (BTE). Figure7 Shows that the brake thermal efficiency of the engine gradually increased with increase in engine speed at full load. After reaching the maximum value, it then decreased. It was seen that biodiesel blend (B100) have least thermal efficiency. This may be attributed to their lower brake power and low heating value. Similar observation was made by Hussain et al., 2020; Faruque et al., 2020; Dhamaparrabhakaran and karthikeyan, 2020.

Variation of engine speed with brake power (BP). Brake power is the engine net output. From Figure 8 , it could be seen that brake power increased as the speed increases at full load and decreased after reaching a maximum value. Moreover, brake power of the engine with fossil diesel was higher than biodiesel and blends at any speed. This is due to lower calorific value of biodiesel and its blends, the observation is in line with the findings of Hussain et al., 2020; Faruque et al., 2020 and Panda et al., 2010.

Variation of $\mathrm{CO}$ emission with load for gmelina seed fatty acid methyl ester (FAME). Figure 9 Shows the variation of $\mathrm{CO}$ emission with load. It was seen that $\mathrm{CO}$ emissions reduced as biodiesel content increases. Also as the engine load increases, the CO emission increases due to decrease in air-fuel ratio in the engine. Similar observation was made by Hussain et al., 2020; Faruque et al., 2020; Dhamaparrabhakaran and karthikeyan, 2020.

Variation of $\mathrm{NO}_{\mathrm{X}}$ emission with load for gmelina seed fatty acid methyl ester (FAME). Figure 10 shows the variation of $\mathrm{NO}_{\mathrm{x}}$ with load. It indicates that $\mathrm{NO}_{\mathrm{x}}$ emissions increases with increase in biodiesel content, the observation is in line with the findings of Hussain et al., 2020; Faruque et al., 2020 and Panda et al., 2010.

Variation of hydrocarbon (HC) emission with load for gmelina seed fatty acid methyl ester (FAME), fossil diesel and bends. Figure 11 shows the variation of $\mathrm{HC}$ emission with load. It shows that $\mathrm{HC}$ emission reduces with increase in biodiesel content. $\mathrm{HC}$ emission for biodiesel increases with increase in load, the observation is in line with the findings of Hussain et al., 2020; Faruque et al., 2020. 


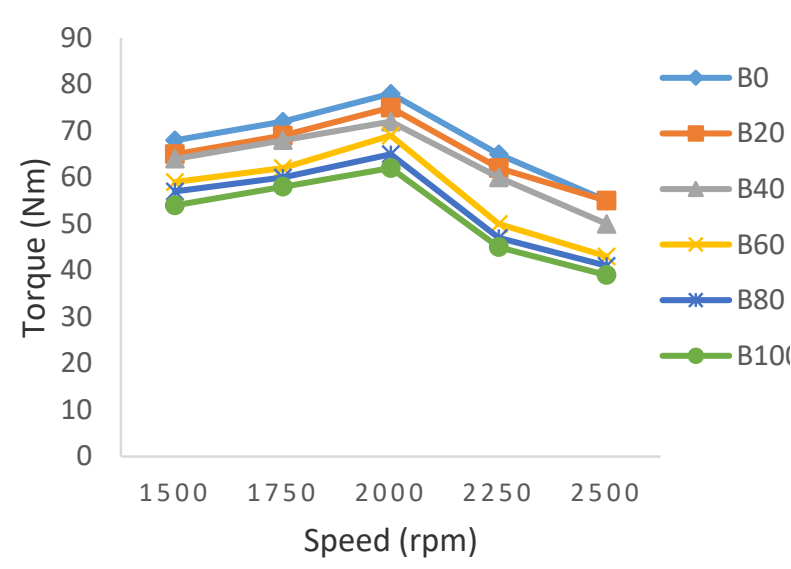

Figure 5: Variation of engine speed with torque

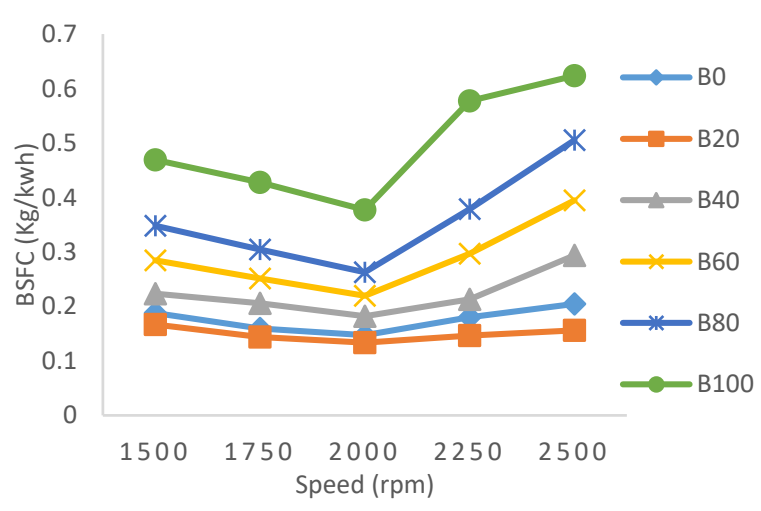

Figure 6: Variation of brake specific fuel consumption with speed

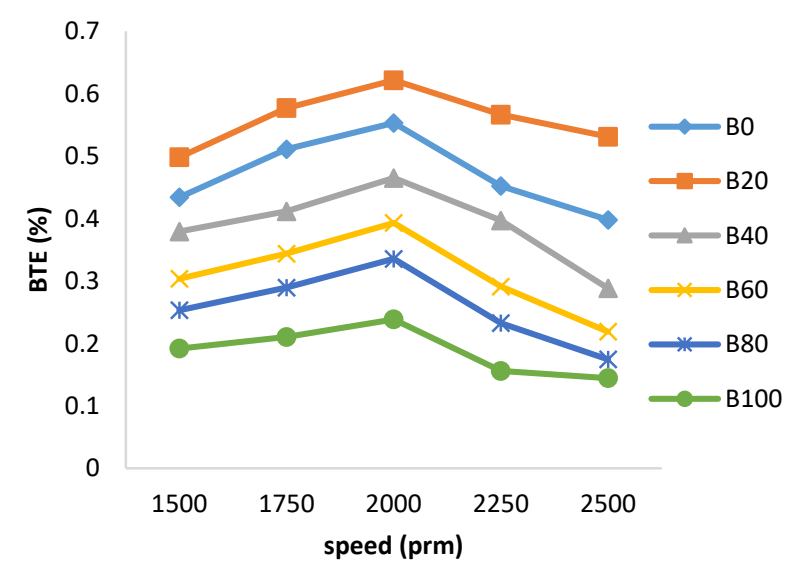

Figure 7: Variation of brake thermal efficiency with speed

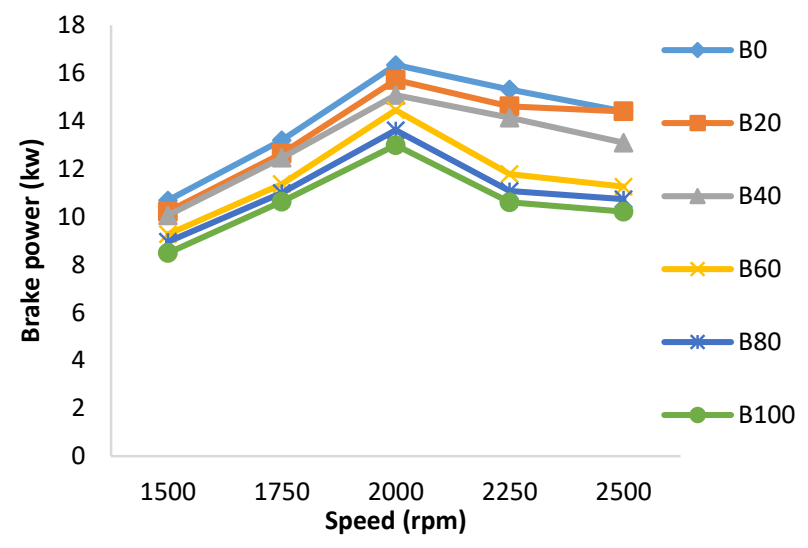

Figure 8: Variation of engine speed with brake power (BP)

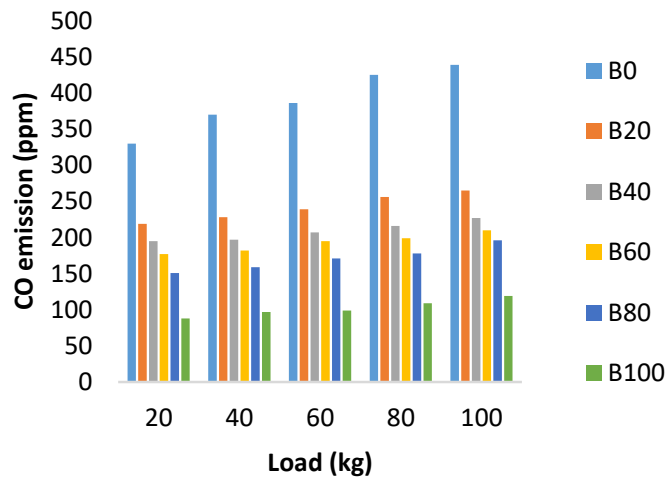

Figure 9: Variation of $\mathrm{CO}$ emission with load

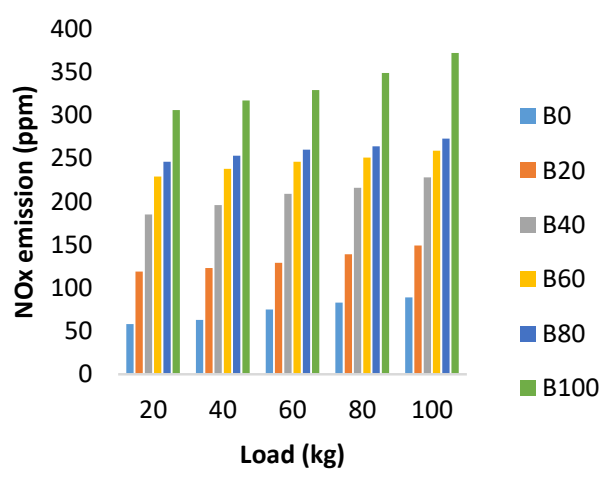

Figure 10: Variation of $\mathrm{NO}_{\mathrm{x}}$ emission with load 


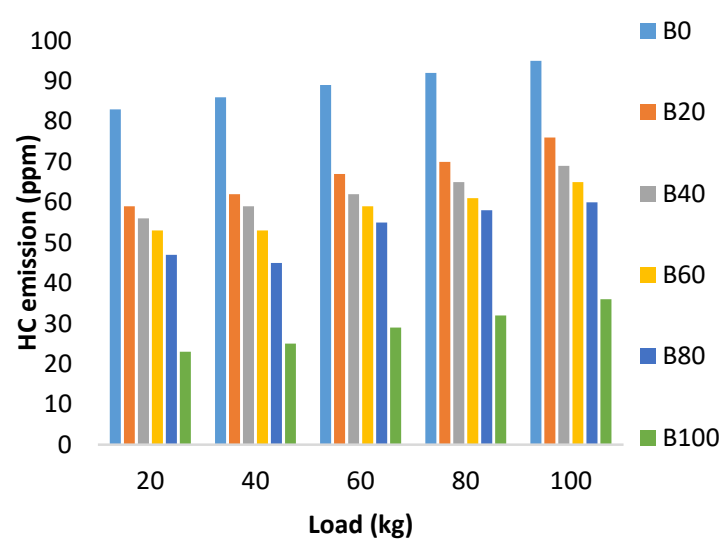

Figure 11: Variation of hydrocarbon (HC) emission with load

\section{Conclusion}

Diesel engine performance evaluation on transesterified gmelina seed oil catalysed by thermally modified Iyi-Nsukka kaolin clay catalyst compared to fossil diesel and blends were done, the catalyst was prepared and characterised as well as the oil, biodiesel and blends. The torque, the brake thermal efficiency (BTE) and the brake power (BP) increases as the engine speed increases up to 2000rpm and started decreasing. However, the torque, the brake thermal efficiency (BTE) and the brake power (BP) of the engine with fossil diesel was higher than biodiesel and its blends. This is attributed to low calorific value of biodiesel and blends. Also it were observed that fuel consumption increase when using biodiesel, but this trend reduced as the proportion of biodiesel reduces in the blends. It was seen that $\mathrm{CO}$ and $\mathrm{HC}$ emissions reduced as biodiesel content of the blends increases while NOx emissions incresed as biodiesel content of the blends increases, this trend makes B20 economically and ecologically friendly fuel with its performance very close to the performance of fossil diesel B0 


\section{Reference}

1. Atadashi, I. M., Aroua, M. K., Aziz, A.R.A. \& Sulaiman, N.M.N. (2013). The effects of catalysts in biodiesel production: A review. Industrial and engineering chemistry journal, 19, 14-26.

2. Demirbas, A. (2009). Progress and recent trends in biodiesel fuels. Energy conversion and management journal, 50,14-34.

3. Dhamaparabhakaran, T. and Karthikeyan, S. (2020). Emission analysis of $\mathrm{CuO}$ nanoparticule addition with blends of botryocoecus brauii algea biodiesel on CI engine. Elsevier journal 33(7), 2897-2900

4. Diko, M., Ekosse, G., \& Ogala, J. (2016).

Fourier transform infrared spectroscopy and thermal analysis of kaolinitic clay from South Africa and Cameroon. Acta geodynamica et geromaterialia, 13, 2, 149.

5. Faruque, M. O., Razzak, S.A. \& Hossain, M.M. (2020).Application of heterogeneous catalysts for biodiesel production from microalgal oil- A review. Catalysis journal, 10 (9) 1025.

6. Hama, S. \& Kondo, A. (2013). Enzymatic biodiesel production: an overview of potential feedstocks and process development. Bioresources technology journal, 135, 386395.

7. Hussain, F., Soudagar, M., Afzal, A. \& Mujtaba, M. (2020). Enhancement in combustion, performance and emission characteristics of diesel engine fuelled with $\mathrm{Ce}-\mathrm{ZnO}$ nanao particle additive added to soya beans biodiesel blends. Energies journal, 13 (17), 4578.

8. Knothe, G., Cermak, S. C. \& Evangelista, R. L. (2009). Cupher oil as source of biodiesel with improved fuel properties. Energy and fuels journal, 23, 1743-1747.

9. Maryam, T., Hosseni, K. \& Morteza, T. (2014). Synthesis and characterisation of zeolite nay using kaolin with different syntheses methods. Clay and clay minerals journal, 82, 508-518.

10. Meher, L.C., Sagar, D.V. \& Naik, S.N. (2006). Technical aspects of biodiesel production by transesterification: A review. Renewable sustainable energy reviews. 10, 248-268.

11. Mittelbach, M. \& Remschmidt, C. (2006). Biodiesel: The comprehensive handbook. 3rd edition, Graz, Austria, ISBN-13: 9783200002494, pp. 332

12. Mujtaba, M. A., Masjuki, H. H., Kalem, M. A., Farooq, M. \& Noor, F. (2020). Effects of additivied biodiesel blends on diesel engine performance, emission, tribiogical characteristics. Energies journal, 13 (13), 3375.

13. Omidvarborna, H., Kumar, A. \& Kim, D. (2014). Characterization and exhaust emission analysis of biodiesel in different temperature pressure and laboratory study. Hazardous, toxic and radioactive waste journal, 19(2)

14. Oueda, N., Bonz-Coulibaly, Y. L. \& Ouedraogo, I. W. K. (2017) Deactivation process, regeneration conditions and reusability performance of $\mathrm{CaO}$ or $\mathrm{MgO}$ based catalysts used for biodiesel production - A review. Materials sciences and applications journal, 8, 94-122

15. Panda, B., Achyut, K., Mishraa, D.K., Mishrac, D. \& Singha, R. (2010) Colloids and surfaces A: Physicochemical engineering aspects. Applied clay science journal, 363, 98-10

16. Park, Y.M., Lee, D. W., Kim, D. K., Lee, J. S. \& Lee, K. Y. (2008). The heterogeneous catalyst system for the continuous conversion of free fatty acids in used vegetable oils for the production of biodiesel. Catalysis today, 131: 238-243.

17. Sani, Y.M., Daud, A.W. \& Aziz, A.R.A. (2014). Activity of solid acid catalysts for biodiesel production: A critical review. Applied 
catalysis A journal: general, 470, 140-161.

18. Sharma, Y.C., Singh, B. \& Korstad, J. (2011). Latest developments on application of heterogenous basic catalysts for an efficient and eco-friendly synthesis of biodiesel: A review. Fuel journal, 90, 1309-1324.

19. Singh, S. P. \& Singh, D. (2010). Biodiesel production through the use of different sources and characterization of oils and their esters as the substitute of diesel: A review. Renewable and sustainable energy journal, 14 , 200-216.

20. Talebian-Kiakalaieh, A., Amin, N. \& Mazaheri, H. (2013). A review on novel processes of biodiesel production from waste cooking oil. Applied energy journal, 104: 683-710.

21. Vashist, D. \& Ahmad, M. (2005). Statistical analysis of diesel engine performance for castor and jatropha biodiesel-blended fuel. International automotive journal 28, 77-86.

22. Xu, L., Yang, X., Yu, X., Guo, Y.\& Maynurkader, E. (2010). Preparation of mesoporous polyoxometalate-tantalum pentoxide composite catalyst for efficient esterification of fatty acid. Catalysis community journal, 9, 1607- 1611.

23. Yusoff, M. H., Ayoub, M., Juisoh, N. \& Abdullah, A. Z. (2020). The challenges of biodiesel implementation program in Malaysia. Processes journal, 8 (10), 1244 